\title{
AGRICULTURAL GROWTH AND AGRARIAN STRUCTURE IN THE BRAZILIAN CERRADO: THE ROLE OF LAND PRICES, NATURAL RESOURCES AND TECHNOLOGY
}

\author{
Gervásio Castro de Rezende ${ }^{1}$
}

\begin{abstract}
This paper argues that the rapid agricultural expansion of the cerrado regions in Brazil is due to the low price of land in these regions, as compared with the other agricultural regions of Brazil and abroad. This low price of land is, in turn, attributed not only to the greater distance of these regions from the main markets, but also to the limitations of natural resources (the extremely harsh drought period, which limits agricultural activities to grains and livestock) and, above all, to technological innovations that "produced" an abundance of land of good quality. In order to show more clearly how this process has taken place, the paper develops a model of the land market that allows for "production of land," and derives the implications of such a model for production functions and total factor productivity (TFP) analyses. The paper also seeks to explain why the agrarian structure of the cerrado is so concentrated. The explanation turns on the low price of land and the peculiar characteristics of the natural resources and technology, rather than the role of agricultural policies. In its conclusions, the paper derives some implications for environmental as well as agrarian reform policies.
\end{abstract}

Keywords: The cerrados in Brazil, technology, land markets, agricultural growth, agrarian structure.

\section{Introduction}

The dramatic change in the agricultural potential of the cerrado soils in Brazil, thanks to the discovery of a solution to the serious problems of low natural fertility and excessive acidity, is well known. ${ }^{2}$ According to Cunha

\footnotetext{
${ }^{1}$ IPEA - Researcher. Address: Av. Pres. Antônio Carlos, 51/150. Rio de Janeiro - RJ. 20.020-010.

E-mail: grezende@ipea.gov.br.

${ }^{2}$ As is well known, the cerrado soils could not originally be used for agriculture due to the excessive acidity and toxicity of the soils. The solution consists in correcting this excessive toxicity by liming, together with proper fertilization of the soils. See Warnken (1999: 32).

Recebido em 10/01/2003 Aceito em 14/02/2003
} 
(1994:124), this technological solution amounted to a process of "construction of the soil," so that, "from a natural resource, inherited, the cerrado soils were transformed themselves into capital, artificially produced."

The importance of these technological innovations for Brazilian agriculture cannot be overestimated. According to Embrapa, the Brazilian agricultural research agency, the cerrado regions occupy an estimated area of 204 million hectares, $25 \%$ of the total area of Brazil, though only 66 million hectares of this area are currently being used for agricultural production. Embrapa projects that an aditional 66 million hectares are suited to agricultural use and that the other 77 million hectares are not suited for agricultural use. If this unusable area is preserved for environmental purposes, while utilizing the entire usable portion, then the legal requirement that at least $25 \%$ of the area should be preserved for environmental purposes can be satisfied at a low opportunity cost for the economy.

The objective of this paper is to show that the agricultural growth in the cerrado regions under the new technology, starting in the 1970's and still continuing today at a fast rate, is a phenomenon closely associated with such a "construction of the soil," and the resulting low price of good agricultural land in the cerrado regions vis-à-vis the other agricultural regions of the country and abroad.

This paper is organized into 5 sections, beginning with this introduction. In section 2, after comparing land prices in the cerrado regions with land prices in the other regions of the country, I show the connection between low land prices, on the one hand, and product mix and agrarian structure in the cerrado, on the other hand. Section 3 proposes a model whose purpose is to show how "production of land" happens in the cerrado and how such a "production of land" out of abundant, low-quality soils, is capable of keeping down the price of good quality land in the cerrado. Section 4 presents some implications for the analyses of production functions and Total Fator Productivity (TFP). A final section presents the summary and conclusions. 


\section{Product mix and agrarian structure in the Cerrado: The role of land prices and natural resources}

Data from Getulio Vargas Foundation show that crop land prices in São Paulo and Parana have been 4 to 6 times higher than the crop land prices of Mato Grosso since the mid-1970's, while crop land prices in Rio Grande do Sul have always been at least 3 times higher. There is an even more dramatic difference in land prices between the cerrado and agricultural areas in other countries. For example, according to Schnepf et alii (2001: 56), the price of land in Illinois is no less than 10 times higher than the price of land in Mato Grosso.

The best evidence pointing to the role that these low land prices play in the cerrado's agricultural growth is the product mix of agriculture in the region, marked by a preponderance of grains and livestock. It is well known that these activities use land intensively; and land is, precisely, the cheapest agricultural factor of production in these regions.

Note, however, that the choice of these activities is also due to the severe climate that prevails in the cerrado regions, marked by a long period of drought that prevents other crops from being grown without the use of irrigation. ${ }^{3}$ Due to the harshness of this drought period in the cerrado regions, the opportunity cost of using cerrado land for grain and livestock production is practically zero, a fact that increases the competitiveness of these activities in these regions and reduces the price of land as well.

The greater distance to markets also prevent from being grown in the cerrado a whole set of agricultural activities that have to be grown near the markets. According to the classical analysis of von Thünen, this lowers the price of land in the cerrado and raises the competitiveness of activities like grains and livestock, that use land intensively and do not "suffer" as much with the greater distance to markets.

The peculiar climatic conditions make the family farm absolutely unfeasible in the cerrado, since it is impossible to earn income during the drought period and therefore to satisfy the familiy's consumption needs

\footnotetext{
${ }_{3}^{3}$ According to Warnken (1999: 32), this climatic problem is aggravated by high evapo-transpiration and the small capacity of the typical cerrado soils to retain water.
} 
during that period. This problem is further aggravated by the lack of employment opportunities in the rural labor market during the drought period.

It is also noteworthy that the attractiveness of livestock in the cerrado regions also disfavors access to land by the small farmer, since livestock requires a large land area and too much capital (in the form of animals) as a startup cost.

On the other hand, the fact that land in the cerrado regions is typically very flat and, as pointed out by Warnken (1999: 32), that the greater part of cerrado soils is deep, well drained and endowed with excelent physical characteristcs, imply that the unit cost of mechanized production becomes lower than the cost of non-mechanized production in the cerrado. ${ }^{4}$ In view of the indivisibility of machines and the lack of a market for the renting of machines, investment in machinery, besides being very high, has to be carried out by the farmer himself. This disfavors the small farmer, since his access to credit is more limited. Furthermore, in these circunstances the fixed cost of machinery (consisting of depreciation, maintenance and interest on capital) per unit of output is smaller the larger the scale of production. Thus, the dominance of large-scale over small-scale production in the cerrado regions is due not to the presence of economies of scale, but to this superiority of mechanized production and harvesting over non-mechanized production and to the difficulties faced by small farmers to adopt mechanized produciotn. To the extent that large-scale production presupposes large land area, the low price of land also contributes to the prevalence of large scale production in the cerrado. Just to give an idea of how large is the scale of production in the cerrado regions, it suffices to say that, according to Schnepf, Dohlman and Bolling (2001: 13), two thirds of the soybean farms in the cerrado regions have an area greater than 1000 hectares, in contrast with the soybean farms in the South of Brazil (average area of 30 hectares) and with the soybean farms in the U.S. (Corn Belt), whose average area is from 120 to 150 hectares.

${ }^{4}$ Sanders and Bein (1976: 598-602) argue that the harsh drought also makes the use of machinery more profitable. 


\section{A Model of the land market with the production of land}

Since the discovery, as far back as the mid-1970's, of a technical solution to the problems of low fertilily and hign acidity of cerrado soils, a huge area of low-productivity lands has been tapped and converted into highproductivity soils, whose supply has been growing systematically since then. This, in turn, has kept down the prices of these high-productivity cerrado lands, notwithstanding the fast agricultural growth in the cerrado regions that has occurred since then. ${ }^{5}$

The model of the land market that follows is an attempt at explaining this mechanism of a continuous conversion of inferior lands into superior lands, thanks to which land prices are kept low, notwithstanding fast regional agricultural growh. In this model there are three types of land: superior land, inferior land and virgin land. It is assumed that both lowquality and virgin lands can be converted into high-productivity land. It is further assumed that the low-quality land is already used in agriculture, while virgin land is usable, but only after conversion. For simplification, the superior land will be called "land 1", the inferior land will be called "land 2", and virgin land will be called by its name.

The main characteristic of the model is a sharp distinction between shortrun and long-run equilibria. In the short-run, the stock of land is given and the land price is determined exclusively by the forces of demand. In the long-run, however, since we allow for change in the stock of land, forces arising from the side of supply of land also play a role in the determination of land prices. In fact, they become the determining factor.

\subsection{The market for "Land 1"}

\subsubsection{Equilibrium in the short-run}

Consider the following system of equations:

${ }_{5}^{5}$ On the fast expansion of grain production in the cerrado regionis, see Helfand and Rezende (2000). 


$$
\begin{aligned}
& \mathrm{L}_{1 \mathrm{t}}^{\mathrm{d}}=\mathrm{L}_{1 \mathrm{t}}^{\mathrm{d}} \stackrel{(-)}{\left.\mathrm{r}_{1 \mathrm{t}}, \cdots\right)} \\
& \mathrm{L}_{1 \mathrm{t}}^{\mathrm{s}}=\mathrm{k} \cdot \mathrm{S}_{1 \mathrm{t}} \\
& \mathrm{L}_{1 \mathrm{t}}^{\mathrm{d}}=\mathrm{L}_{1 \mathrm{t}}^{\mathrm{s}} \\
& \mathrm{p}_{1 \mathrm{t}}=\mathrm{p}_{1 \mathrm{t}}\left(\stackrel{(+)}{\mathrm{r}} \mathrm{rt}_{\mathrm{t}} \stackrel{(-)}{\mathrm{i}}, \cdots\right)
\end{aligned}
$$

where $\mathrm{L}_{1 \mathrm{t}}^{\mathrm{d}}$ is the quantity of land 1 services demanded in year $t ; \mathrm{L}_{1 \mathrm{t}}^{\mathrm{s}}$ is the quantity of land 1 services supplied in year $\mathrm{t}$; $\mathrm{k}$ is a constant of proportionality that converts a unit of stock into a unit of service; $S_{1 t}$ is the stock of land 1 in year $t ; r_{1 t}$ is the value of land 1 rent in year $t ; p_{1 t}$ is the price of land 1 in year $t ; i$ is the interest rate.

Note that equation (2) expresses the usual hypothesis that the supply of land services, given the available stock, is absolutely inelastic. This hypothesis assumes implicitly that we are dealing with aggregate agricultural output, and that land can only be used in agriculture. In an urbanized region, by contrast, land has alternative uses, and the supply of land services to a particular use (such as agriculture) is not absolutely inelastic anymore. In what follows, we will assume also that there is always a positive value of such that the market for land services clears, so that all land is always used.

As shown in Figure 1, this model can be solved recursively; the solution (see Graph A) involves, first, the determination of the value of rent (solution to equation 3$) ; \mathrm{p}_{1 \mathrm{t}}$, the price of land, is then formed as the capitalized value of rent $\left(p_{1 t}=r_{1 t} / i\right)$ (see Graph B). By assuming that the price of land is the discounted value of current rent alone, it is assumed that current rent is projected into the future, ad infinitum. It is also assumed that the interest rate is the same for all periods. 
Figure 1: Graphical Solution

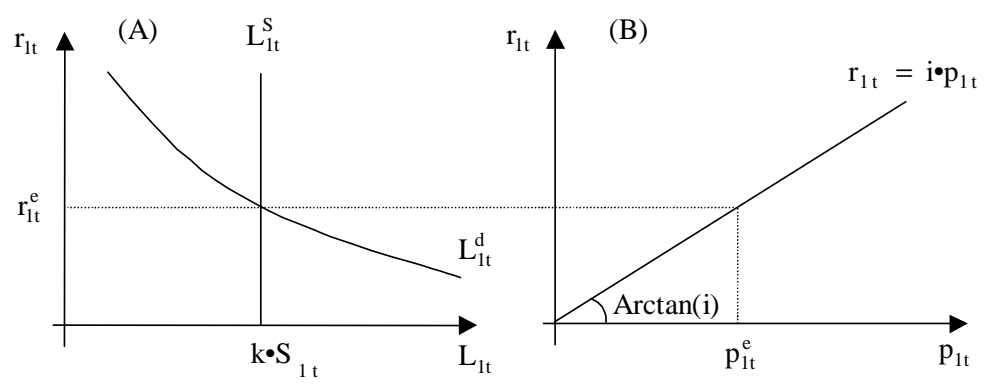

\subsection{2 - Equilibrium in the long-run}

To this system, we add Equation 5, to allow for changes in the stock of land 1 over time, thanks to the conversion of land 2 into land 1 . The amount of land 1 created each year $\left(\Delta \mathrm{S}_{1 \mathrm{t}}\right)$ is a function of the prices of land 1 and $2\left(\mathrm{p}_{1 \mathrm{t}}\right.$ and $\left.\mathrm{p}_{2 \mathrm{t}}\right)$ and of the cost of such a conversion, $\mathrm{c}_{2 \mathrm{t}}$ :

$$
S_{1(t+1)}=S_{1 t}+\Delta S_{1 t}\left(p_{1 t}-p_{2 t}, c_{2 t}\right)
$$

According to the model if $\mathrm{p}_{1 \mathrm{t}}>\mathrm{p}_{2 \mathrm{t}}+\mathrm{c}_{2 \mathrm{t}}$, then $\Delta \mathrm{S}_{1 \mathrm{t}}$ would be positive, $S_{1 t}$ would be moving to the right in Graph A, pushing down $r_{1 t}$ and $p_{1 t}$. Eventually, $p_{1 t}$ would fall to a point where $p_{1 t} \leq p_{2 t}+c_{2 t}$, and the stock of land $1 \mathrm{~S}_{1 \mathrm{t}}$ would become stable; this is the long-run equilibrium of the model. Note that the model can be made more realistic by assuming that land 1 depreciates; in this case, the stock of land 1 could diminish through time, in absolute terms. The long-run equilibrium condition would then be that the stock of land 1 should grow by the same rate as the rate of depreciation. 


\section{2 - The market for Land 2}

As in the case of land 1, whose price is a function of the productive use of the land, the price of land 2 is also determined by the capitalized value of its own rent. However, since this land, in addition to being an input in the production of agricultural goods, is also an input in the production of land 1 , its price suffers the influence of the price of land 1.

Let us suppose that, initially, there is a given stock $S_{2 t}$ of land 2 being utilized in agricultural production. This land is capable of being used in the production of livestock or even crops, with very low productivity levels. The price of this land, before the discovery of the possibility of its convertion into land 1 , was given only by its own capitalized rent, without any influence from the price of land 1, whose price was then very high, due to the scarcity of good cerrado land.

The influence of land 1's price over land 2's price is complex; first of all, it should be noted that, even after the technological breakthrough that made it possible to convert land of type 2 into land of type 1 , the price of land 2 is still, at every moment, the capitalized value of its own rent:

$$
\mathrm{p}_{2 \mathrm{t}}=\frac{\mathrm{r}_{2 \mathrm{t}}}{\mathrm{i}}
$$

Let us suppose, then, that at this price $\mathrm{p}_{1 \mathrm{t}}>\mathrm{p}_{2 \mathrm{t}}+\mathrm{c}_{2 \mathrm{t}}$; in this case, there would be convertion of land 2 into land 1 , so that $S_{1 t}$ would be increasing and $S_{2 t}$ would be decreasing. As a result, $r_{1 t}$ and $p_{1 t}$ would be falling, while $p_{2 t}$ and $r_{2 t}$ would be rising, until a long-run equilibrium is reached:

$$
\mathrm{p}_{1 \mathrm{t}} \leq \mathrm{p}_{2 \mathrm{t}}+\mathrm{c}_{2 \mathrm{t}}
$$


when no new land 1 is formed via the convertion of land 2, and the two land markets are in a simultaneous long-run equilibrium. Note that this analysis presupposes that the sector that converts land 2 into land 1 is small compared to the quantity of land 2 , and for this reason the price of this land is given for this sector.

The long-run equilibrium condition states that, in a way, the price of land 1 is formed independently of the market for its own product, being "anchored" to the price of land 2 and to the cost of conversion of one type of land into the other. In this way, it may be called the fundamental equation of the formation of the price of land 1 as a function of the price of land 2 and the cost of conversion of one land into the other.

This is, of course, a condition to be observed only in the long run, while the determination of the price of either type of land by its own discounted rent has to be observed at every moment in time, as a short-run equilibrium condition.

\subsection{The Market for Virgin Land}

It is interesting to consider now the case in which land 1 is formed through the conversion of virgin land that exists in abundance and that does not generate any rent, agricultural or otherwise, unless it is converted into another type of land. Since the price of this land does not have any floor (contrary to what happens with land 2), it will be determined exclusively as a function of the price of land 1, after subtracting the cost of conversion. In the same way as in the previous analysis for the case of land 2, if $\mathrm{p}_{1 \mathrm{t}}>\mathrm{p}_{\mathrm{vt}}+\mathrm{c}_{\mathrm{vt}}$, where $\mathrm{p}_{\mathrm{vt}}$ is the price of virgin land and $\mathrm{c}_{\mathrm{vt}}$ is the respective cost of conversion, then the sector that produces land 1 can buy virgin land in the market in order to obtain land 2 and sell it at a profit. However, as the stock of land 2 grows, the rent and the price of this land fall, until, in the long run equilibrium, $\mathrm{p}_{1 \mathrm{t}} \leq \mathrm{p}_{\mathrm{vt}}+\mathrm{c}_{\mathrm{vt}}$.

Even though, formally, this long-run equilibrium condition is the same as that derived for the conversion of land 2 into land 1 , there is a fundamen- 
tal difference between the two, since, as the virgin land does not earn any rent (since it is not directly usable in agriculture), its price is formed as a residual and for this reason it does not represent a cost to be covered by the price of land 1 . Thus, it is $p_{v t}$ that is a function of $p_{1 t}$ and not the contrary, as in the case of prices of land 2 and land 1.

It should be noted that the analysis has become more complicated now, since the sector that produces land 1 can choose between land 2 and virgin land as its basic raw material. An interesting conclusion that seems possible in this more complex world is that the use of land 2 for the production of land 1 could become unfeasible, to the extent that land 1 can be obtained more cheaply through the use of virgin land that imposes no own cost in the process of convertion.

\section{Implications for production function and total factor productivity analyses}

The conversion of inferior land into superior land, analyzed above, consists basically in opening up and sistematizing the terrain, followed by applying lime and fertilizers. These are practices that have as their purpose the production of a good (the transformed land) that has to be available before the process of agricultural production, proper, starts, since agricultural production uses this transformed land-combined with the other factors or production, including more fertilizers - not the inferior land. For this reason, there is no direct connection between the allocation of land 2 (or of virgin land), lime and fertilizers, on the one hand, and the production of the agricultural output, on the other hand. Since, in addition, the transformed land is a durable factor of production, it is possible to say that it is a capital good as much as it is land.

Note that production function and total factor productivity (TFP) analyses usually do not include this kind of good produced in agriculture-capital goods - in their measure of agricultural output. As a matter of fact, a number of capital goods are produced in agriculture, but usually not included in the output index, including planted pasture, trees that produce 
permanent crops, and animals bred to be retained in the agricultural sector (steer, milk cows), among other things. This problem is aggravated by the fact that the inputs used in the production of these capital goods usually are included. It is interesting to note, in addition, that these capital goods, once produced, become factors of production in agriculture, but they are rarely included, as such, in all their diversity, in these production funcion and TFP analyses.

\section{Summary and conclusions}

This paper proposed that modern agricultural growth in the cerrado regions in Brazil should be analysed on the basis of a model of the land market in which there occurs a continuous increase in the stock of superior land, through the conversion both of other lands under current use, and virgin lands under no current use. It is this permanently increasing stock of good-quality land-and, even more than that, the perspective of a continuous increase in this stock, due not only to the abundance and to the low price of the lands to be converted, but also to the relatively low cost of this conversion-that is keeping the price of cerrado land low. This low price is the key to the competitiveness of the cerrado regions at home and abroad.

This paper has argued, also, that it is the low price of land in the cerrado that explains the dominance of grains and livestock in the region's product mix. The predominance of these activities is attributed, also, to the peculiar climate and to the greater distance to the markets, that restrict the competitiveness of other activities for the use of land, leading, therefore, to a fall in its price.

The paper also presented some hypotheses to explain the predominance, in cerrado agriculture, of large-scale production, and very little role played by family farms. The explanation focuses on the peculiarities of the natural resources and on the low price of land itself, rather than on agricultural policies. 
The analysis presented in this paper leads also to a conclusion that is of great interest for the discussion of government environmental policy for the cerrado: the recognition that, unlike the Amazon, where, due to the low agricultural capability of the soils, the opportunity cost of forest preservation is low, in the case of the cerrado this opportunity cost is high, with the exception of the areas in which the agricultural potential is very low. Since, according to Embrapa, these areas represent a total of 77 million hectares, more than the $20 \%$ required by the government for preservation purposes, the government should adopt a zoning regime for Brazilian environmental policy in the specific case of the cerrado, assigning only to these areas with lower agricultural potential the prohibition against opening-up new areas for agriculture. This result is contrary to current proposals for a "moratorium" for the cerrado, consisting of the limitation of the conversion of land to "degraded" pastures, prohibiting the incorporation of new cerrado lands. ${ }^{6}$ The problem with this proposal is that the restriction of conversion to lands that are being used today as pastures, even "degraded" ones, will cause the price of higher-productivity land to rise, since the production of superior land out of existing pastures, even "degraded" ones, will be more expensive than the alternative of conversion of virgin land. It is no mere coincidence that one observes, today, a continuous expansion of cerrado agriculture in the direction of virgin lands, rather than intensifying the use in the areas already occupied by livestock.

Finally, another zoning rule seems to be particularly necessary for the success of the agrarian reform policy in the cerrado regions, in order to minimize the risk of choosing areas inadequate for settlements, either because they require too much capital and human resources for agriculture to be competitive, or because they are characterized by more acute drought periods.

\footnotetext{
${ }^{6}$ This proposal is presented in Abramovay (1999).
} 


\section{References}

ABRAMOVAY, R., "Moratória para os Cerrados - Elementos de uma Estratégia de Agricultura Sustentável". Consortium Atech/Emilio Goeldi Museum/PROCAN, Agenda 21, mimeo., 1999.

CUNHA, A S., org., Uma Avaliação da Sustentabilidade da Agricultura nos Cerrados. Brasília, IPEA (Project PNUD/BRA/014), 1994.

HELFAND, S. M. and REZENDE, G. C., "Padrões Regionais de Crescimento da Produção de Grãos no Brasil e o Papel da Região Centro-Oeste". Rio de Janeiro, IPEA, Discussion Paper no. 731, June 2000.

SANDERS, J. H. and F. L. BEIN, "Agricultural Development on the Brazilian Frontier: Southern Mato Grosso", Economic Development and Cultural Change, vol. 24, no. 3, April 1976.

SHNEPF, R. D., DOHLMAN, E. and C. BOLLING, "Agriculture in Brazil and Argentina: Developments and Prospects for Major Field Crops". Washington, Economic Research Service, U.S. Department of Agriculture, Agriculture and Trade Report WRS-01-3, November 2001.

WARnKEN, P. F., The Development and Growth of the Soybean Industry in Brazil. Ames, Iowa: Iowa State University Press, 1999. 
REVISTA DE ECONOMIA E AGRONEGÓCIO, VOL. $1, N^{\circ} 1$ 